\title{
The insect gall collection of the Museu Nacional/Universidade Federal do Rio de Janeiro: biome cerrado, rupestrian fields
}

\author{
Maia, VC. ${ }^{a *}$, Rodrigues, $A$ R. $^{a}$, Ascendino, SHS. ${ }^{a}$ and Boggi, M. ${ }^{a}$ \\ ${ }^{a}$ Laboratório de Diptera, Departamento de Entomologia, Museu Nacional, Universidade Federal do Rio de Janeiro - UFRJ, \\ Quinta da Boa Vista, São Cristóvão, CEP 20940-040, Rio de Janeiro, RJ, Brazil \\ *e-mail: maiavcid@acd.ufrj.br
}

Received: January 21, 2013 - Accepted: May 24, 2013 - Distributed: November 30, 2014

(With 17 figures)

\begin{abstract}
An inventory of the insect gall from Brazilian savanna (Cerrado) was elaborated based on samples of the collection of the Museu Nacional, Universidade Federal do Rio de Janeiro. Data on localities and host plants were obtained from the labels and information about the gall morphology (plant organ of occurrence, shape, and presence of trichomes) by observing the samples. The galling species was determined based on the literature. The collection includes 131 morphotypes of galls from Cerrado, obtained from 71 host plant species distributed in 50 genera and 30 botanical families (Table 1). All galls were collected in rupestrian fields (a rare vegetation physiognomy of the Brazilian Cerrado) in the state of Minas Gerais. As the collection comprises a great diversity of insect galls, it can be considered representative of this physiognomy.
\end{abstract}

Keywords: insect galls, host plants, rupestrian fields, inventory.

\section{A coleção de galhas de insetos do Museu Nacional/Universidade Federal do Rio de Janeiro: bioma cerrado, campos rupestres}

\begin{abstract}
Resumo
Um levantamento de galhas de insetos do Cerrado brasileiro foi elaborado baseado em amostras da coleção do Museu Nacional/Universidade Federal do Rio de Janeiro. Dados de localidades e plantas hospedeiras foram obtidos das etiquetas e informações sobre a morfologia da galha (órgão vegetal de ocorrência, forma, e presença de tricomas) pela observação da amostra. As espécies galhadoras foram determinadas baseadas em literatura. A coleção inclui 131 morfotipos de galhas de Cerrado, obtidos de 71 espécies de plantas hospedeiras, distribuídas em 50 gêneros e 30 famílias botânicas (Tabela 1). Todas as galhas foram coletadas em campos rupestres (uma fisionomia vegetal rara do cerrado brasileiro) do Estado de Minas Gerais. Como a coleção compreende grande diversidade de galhas de insetos, pode ser considerada representativa para essa fisionomia.
\end{abstract}

Palavras-chave: galhas de insetos, plantas hospedeiras, campos rupestres, inventário.

\section{Introduction}

Plant galls are remarkably close associations between arthropods (usually insects) and plants, in which the plant produces an abnormal growth of tissue in response to a specific stimulus from the invading organism. Thus gallformers have the ability to manipulate the growth and development of plant tissues (Shorthouse and Rohfritsch, 1992).

Galling insects are among the most specialised herbivores. From an evolutionary point of view, galls can be seen as adaptations that allowed some insect taxa to feed on high quality tissues, and protect themselves from natural enemies and harsh abiotic factors (Price et al., 1986).

The majority of galling insects are host-plant and plant-organ specific, and gall morphology is specific to each inducer (Floate et al., 1996). In addition, galls may be seen as extended phenotypes of their inducers (Weis et al., 1989).

The insect gall collection of the Museu Nacional, Universidade Federal do Rio de Janeiro began to be organised in 1992, with samples from restinga areas of the state of Rio de Janeiro. Since then, galls from other localities and biomes have been incorporated, increasing the representativeness of the collection.

The main aim of this paper is to elaborate an inventory of the gall collection of the Museu Nacional (MNRJ), focussing exclusively on Cerrado (Brazilian savanna).

The Cerrado covers some 2 million $\mathrm{km}^{2}$ of Central Brazil, representing about $23 \%$ of the land surface of 
the country. In terms of area, it is exceeded only by the Amazonian forest (with approx. $3 \pm 5$ million $\mathrm{km}^{2}$ ). The Cerrado region extends from the margin of the Amazonian forest to outlying areas in the southern states of São Paulo and Paraná, occupying more than $20^{\circ}$ of latitude and an altitudinal range from sea-level to $1800 \mathrm{~m}$ (Ratter et al., 1997).

The Brazilian Cerrado presents diverse physiognomies and comprises one of the richest vascular floras in number of species (Oliveira and Marquis, 2002). It is one of the most threatened biomes, being considered as a diversity "hotspot" (Myers et al., 2000; Jepson, 2005; Marris, 2005). According to Ribeiro and Walter (1998), it includes 11 physiognomies distributed in forest formations (riparian forest, gallery forest, dry forest, and “cerradão"), savanna formations (Cerrado sensu stricto, Cerrado Park, Palmeiral, and Vereda), and grassland formations ("Campo Sujo", rupestrian fields, and "Campo Limpo").
Rupestrian fields are a unique and rare vegetation physiognomy of the Brazilian Cerrado. They spread over the plateaus and mountain chains of the states of Minas Gerais, Bahia, and Goiás, being exclusively found in the highlands of the Espinhaço mountain range and small disjunctions in southeastern and northeastern Brazil. They occur in areas above $900 \mathrm{~m}$ a.s.l., on shallow, Al-rich, waterand nutrient-deficient soils where rocky outcrops prevail (Giulietti et al., 1987; Benites et al., 2007), and include a very high number of endemic species (Giulietti et al., 1987; Giulietti and Pirani, 1988; Safford 1999; Rapini et al., 2002). The plant communities experience high daily thermal amplitudes, strong winds, high sun exposure and constant fires (Ribeiro and Fernandes, 2000; Jacobi et al., 2007). In this speciose physiognomy, plants are mainly sclerophyllous and herbaceous with scattered shrubs and trees comprising a mosaic of habitats (Giulietti et al., 1997). Most of the endangered species of the Brazilian Cerrado are endemic to the rupestrian fields (Menezes
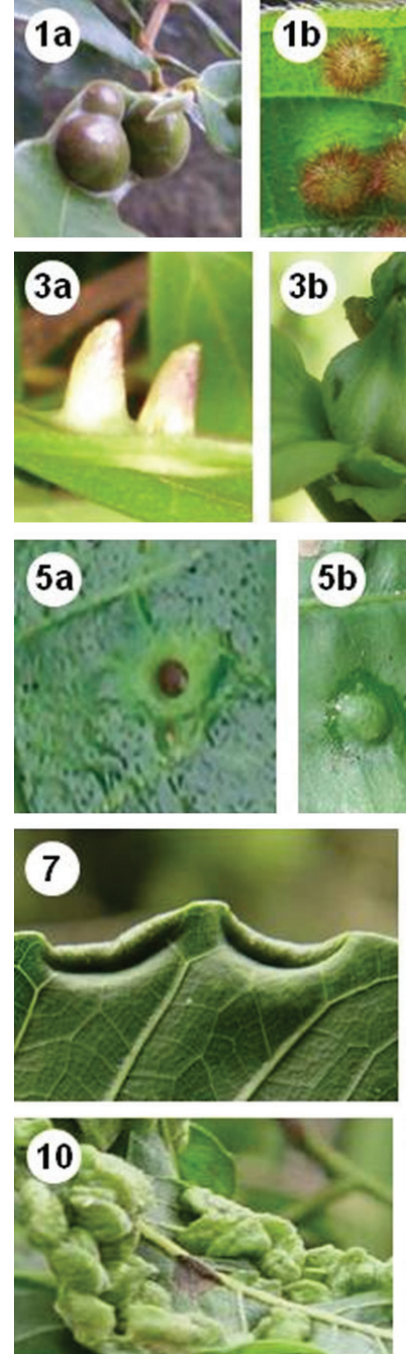
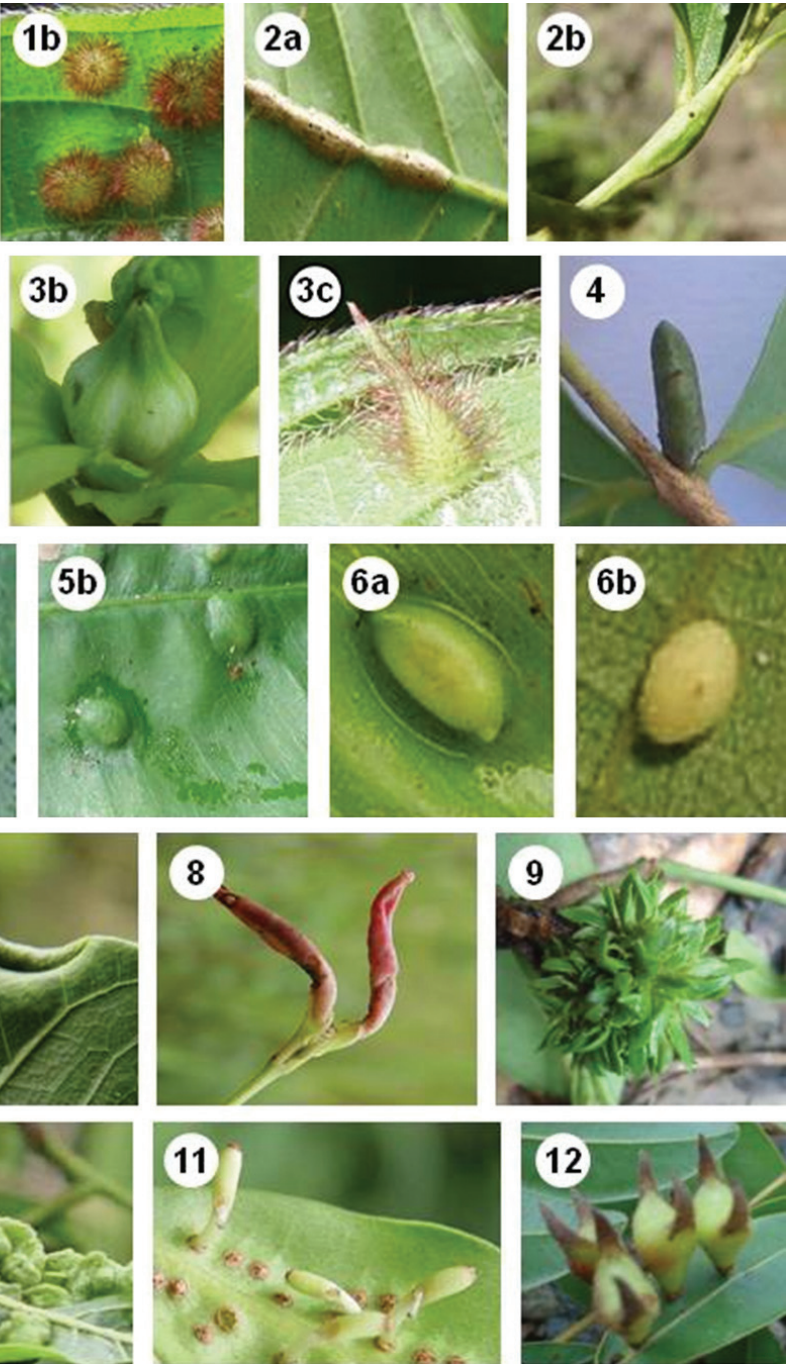

Figures 1-12. Gall shape: 1a, b) globoid; 2) fusiform; 3a-c) conical; 4) cylindrical; 5a, b) circular; 6a, b) ovoid; 7) marginal roll; 8) leaf roll; 9) rosette; 10) vermiform; 11) claviform; 12) horn-shaped. 
and Giulietti, 2000), making this physiognomy especially important for plant conservation.

\section{Material and Methods}

The insect gall collection of the Museu Nacional was surveyed by the authors. Data on localities and host plants were obtained from the labels; the biomes were inferred based on the localities.

Information about the gall morphology (plant organ of occurrence, shape, and presence of trichomes) was obtained by observing the samples. As the shape terminology is not standardised (similar shapes have been receiving different names), we adopt the following synonymies: globoid = spheroid, spherical, globose and fruitform (Figures 1a, b); fusiform $=$ tapered (Figures 2a, b); conical = triangular $=$ mamiliform (Figures 3a-c); cylindrical = tubular (Figure 4); circular $=$ discoid (Figures 5a, b); and ovoid = elliptical, linear (Figures 6a, b), based on Isaias et al. (2013). Other adopted shapes were: marginal roll (Figure 7); leaf roll (Figure 8), rosette (Figure 9), vermiform (Figure 10), claviform (Figure 11), and horn-shaped (Figure 12). The galling species was determined based on literature.

The collection comprises dried galls which are organised in small boxes by host plant names in alphabetical order. The boxes are arranged in wooden drawers covered with glass and these drawers are inserted in compactors (Figures 13, 14).

\section{Results}

The collection comprises 131 morphotypes of galls from Cerrado, which were obtained from at least 71 host plant species distributed in 50 genera and 30 botanical families (Table 1). All galls were collected in a same physiognomy: rupestrian fields.

The samples were collected in five localities of the state


$\mathrm{W})$, Itamonte ( $22^{\circ} 17^{\prime} 02^{\prime}$ S, $44^{\circ} 52^{\prime} 12^{\prime}$ ' W), Serra do Cipó ( $\left.43^{\circ}-44^{\circ} \mathrm{W}, 19^{\circ}-20^{\circ} \mathrm{S}\right)$, São João del Rey (21 ${ }^{\circ} 8^{\prime} 11^{\prime \prime}$ $\mathrm{S}, 44^{\circ} 15^{\prime} 43^{\prime \prime} \mathrm{W}$, Serra do Lenheiro), and Tiradentes ( $21^{\circ}$ $00^{\prime}$ S, $44^{\circ} 00^{\prime} \mathrm{W}$, Serra de São José). No other Cerrado area is represented. The records from Brumadinho, Itamonte and São João del Rey are new.

Melastomataceae was the plant family with the greatest gall richness (15 morphotypes), followed by Asteraceae, Fabaceae, Myrtaceae and Euphorbiaceae (with 14, 13, 12, and 11 morphotypes, respectively) (Table 2). Most of them have a good representativeness in Cerrado areas (Giulietti et al., 1987; Ratter et al., 1997).

Croton (L.) Müll.Arg. (Euphorbiaceae), Miconia Ruiz \& Pav., Eugenia L., Baccharis L., and Byrsonima Rich. ex Kunth were the genera with the greatest gall diversity (with 10, 07, 07, 06, and 06 morphotypes, respectively) (Table 3). Croton floribundus Spreng. and Miconia theaezans Cogn. were the super host plants, with 05 morphotypes each.

The galls were observed on leaves, stems, apical and lateral bud, as well as on flowers (inflorescences, and peduncles), being leaf galls the most frequent galled plant organ (about 60\%) (Figure 15). This result corroborates the world pattern pointed out by Houard (1933).

The most common morphotypes were fusiform (41 morphotypes or ca. 31\%), globoid (36 morphotypes or ca. $27 \%$ ), and circular (15 morphotypes or $11 \%$ ) (Table 4 ). The great majority was glabrous (about $80 \%$ ) (Table 1 ).

The gallers belong to six orders: Diptera, Coleoptera, Hemiptera, Lepidoptera, Hymenoptera, and Thysanoptera,
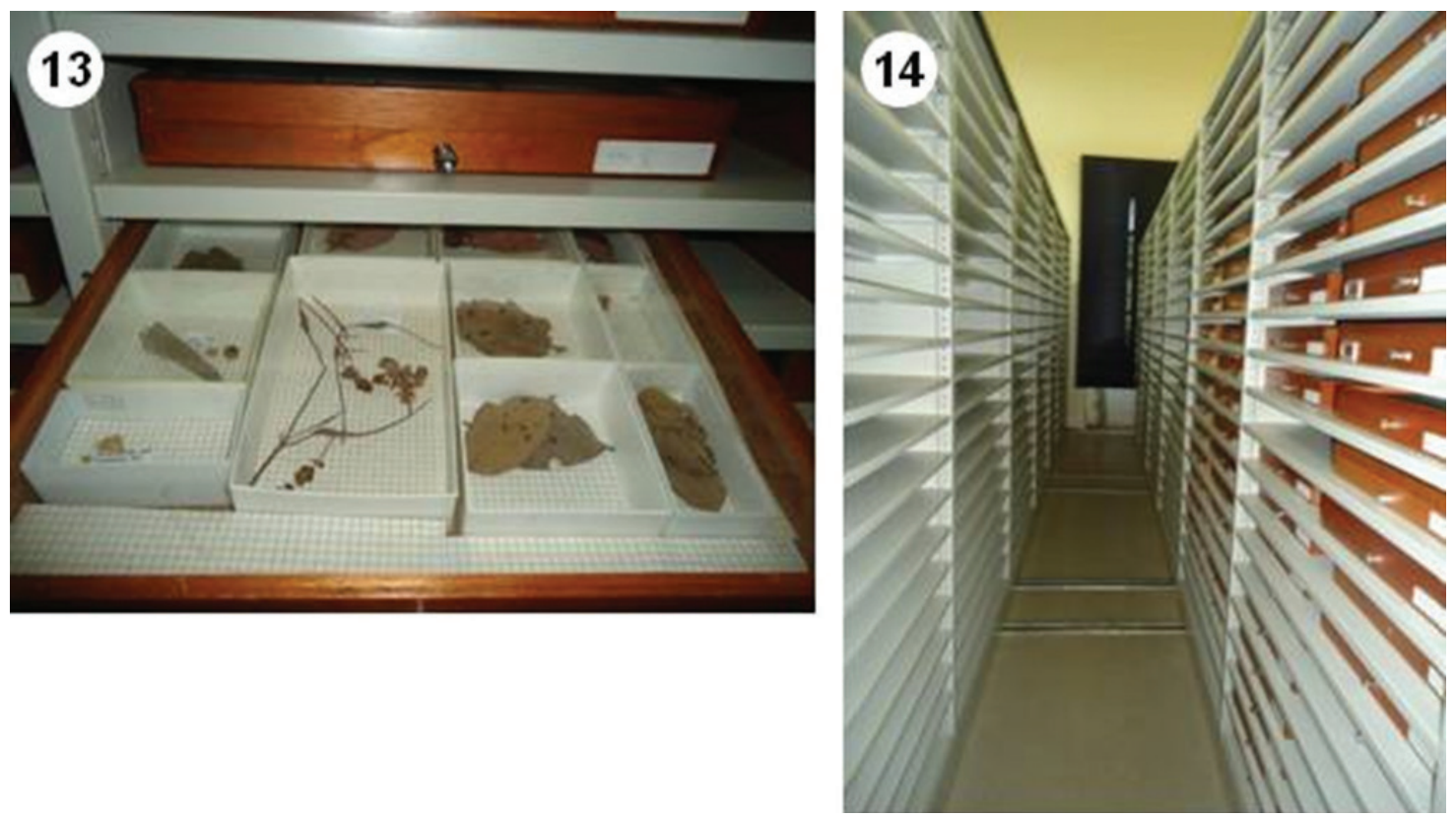

Figures 13-14. The gall collection of Museu Nacional,Universidade Federal do Rio de Janeiro. 




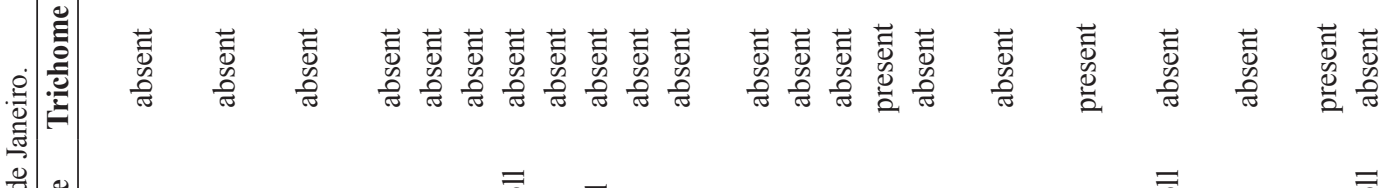

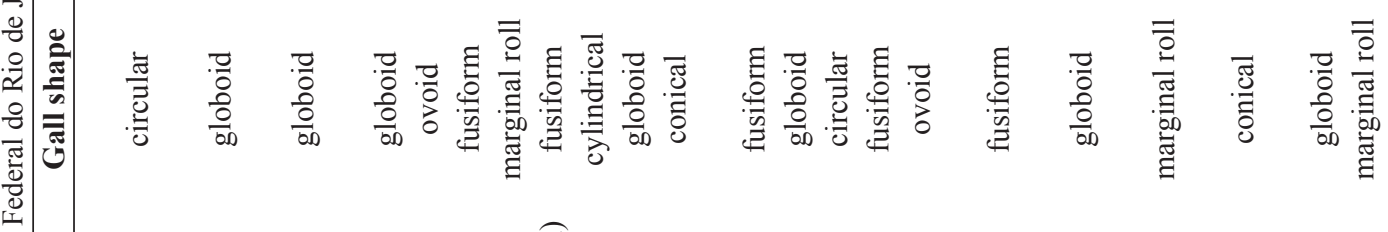

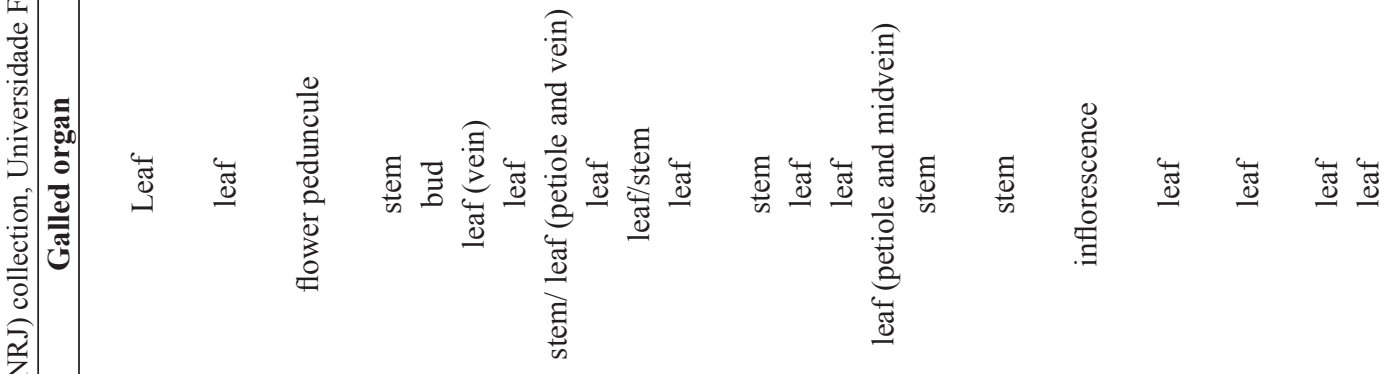<smiles>C1#CCC1</smiles>

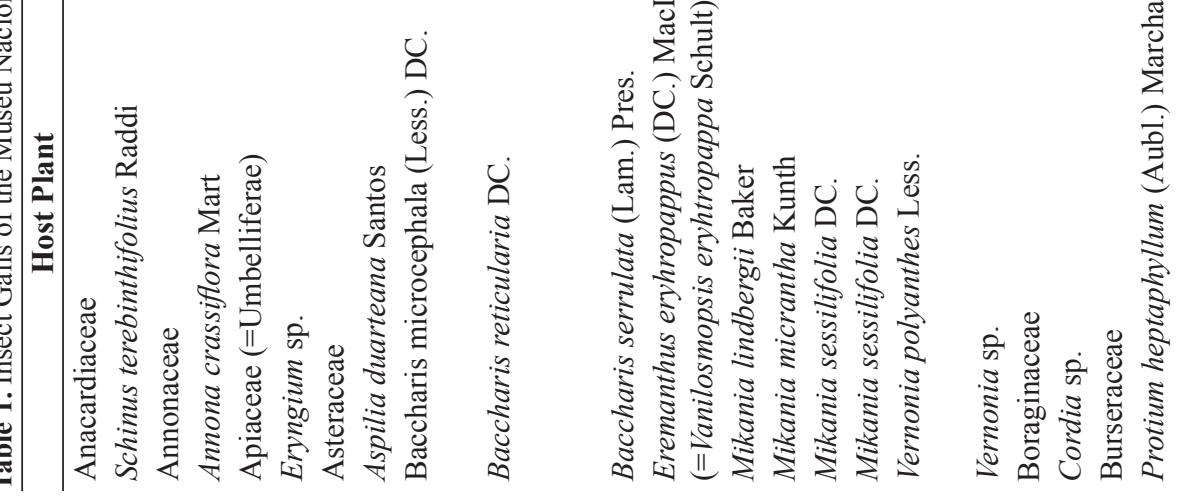






$\sum_{\substack{0 \\ \sum_{0}}}^{0} \sum_{i}^{0} \sum_{0}^{0}$

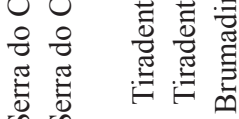



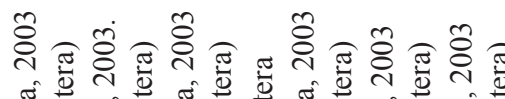

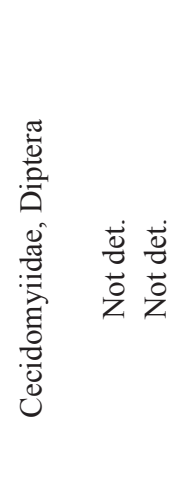

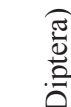

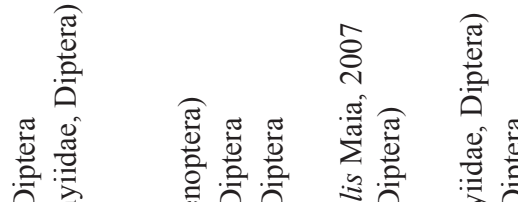

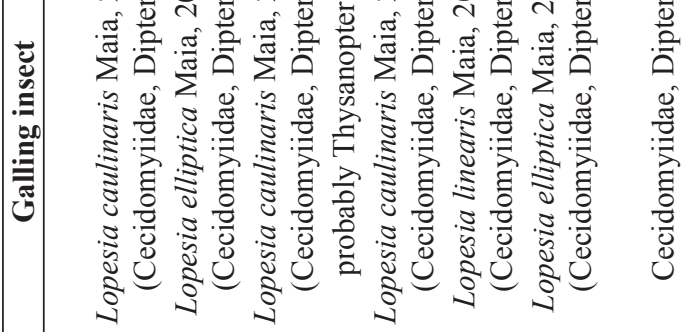

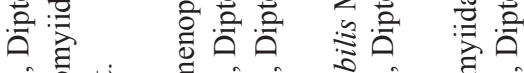

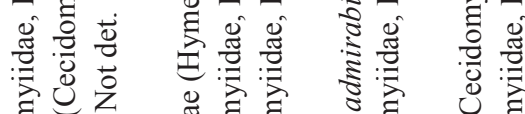

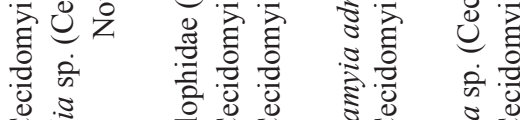

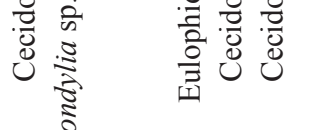
$\frac{\pi}{2}$

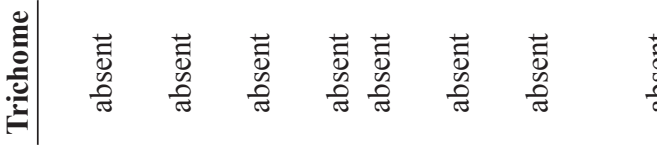

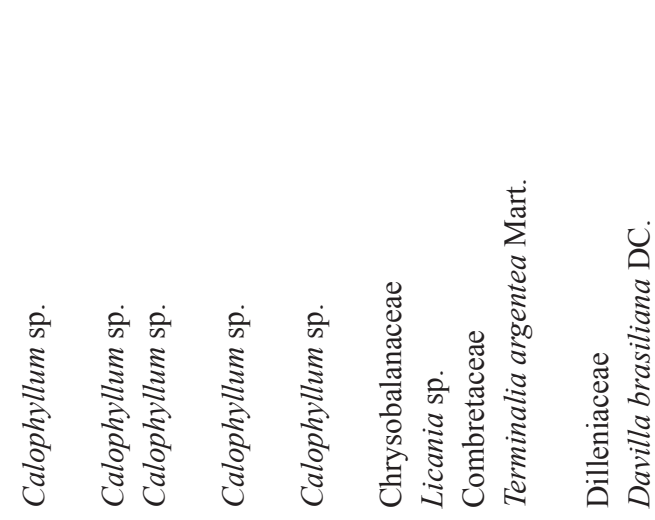

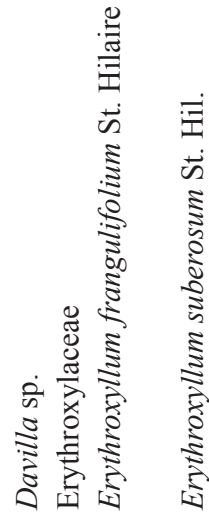




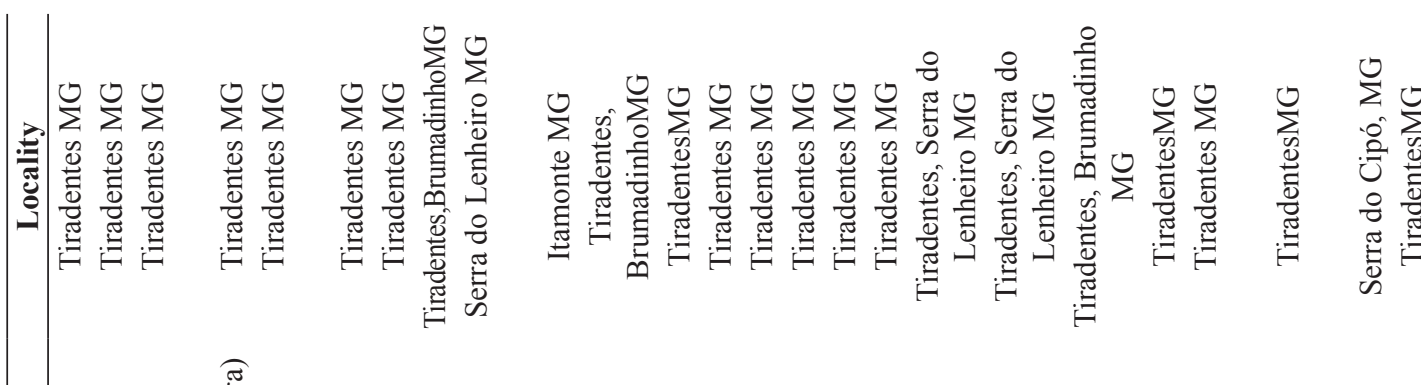

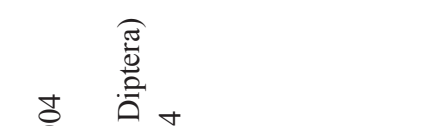



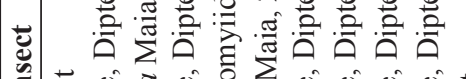

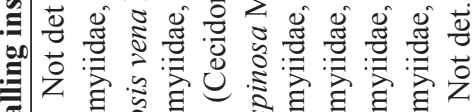

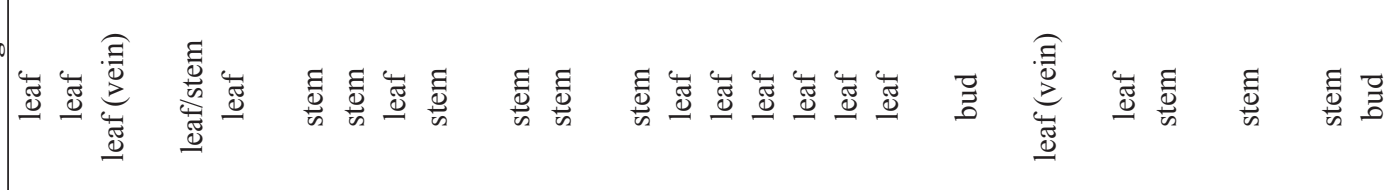
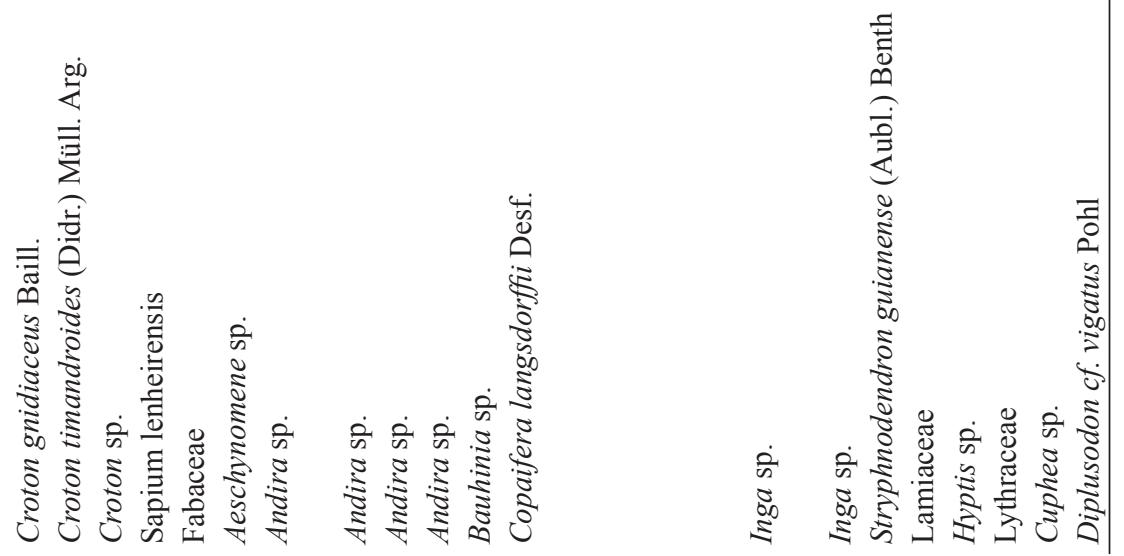


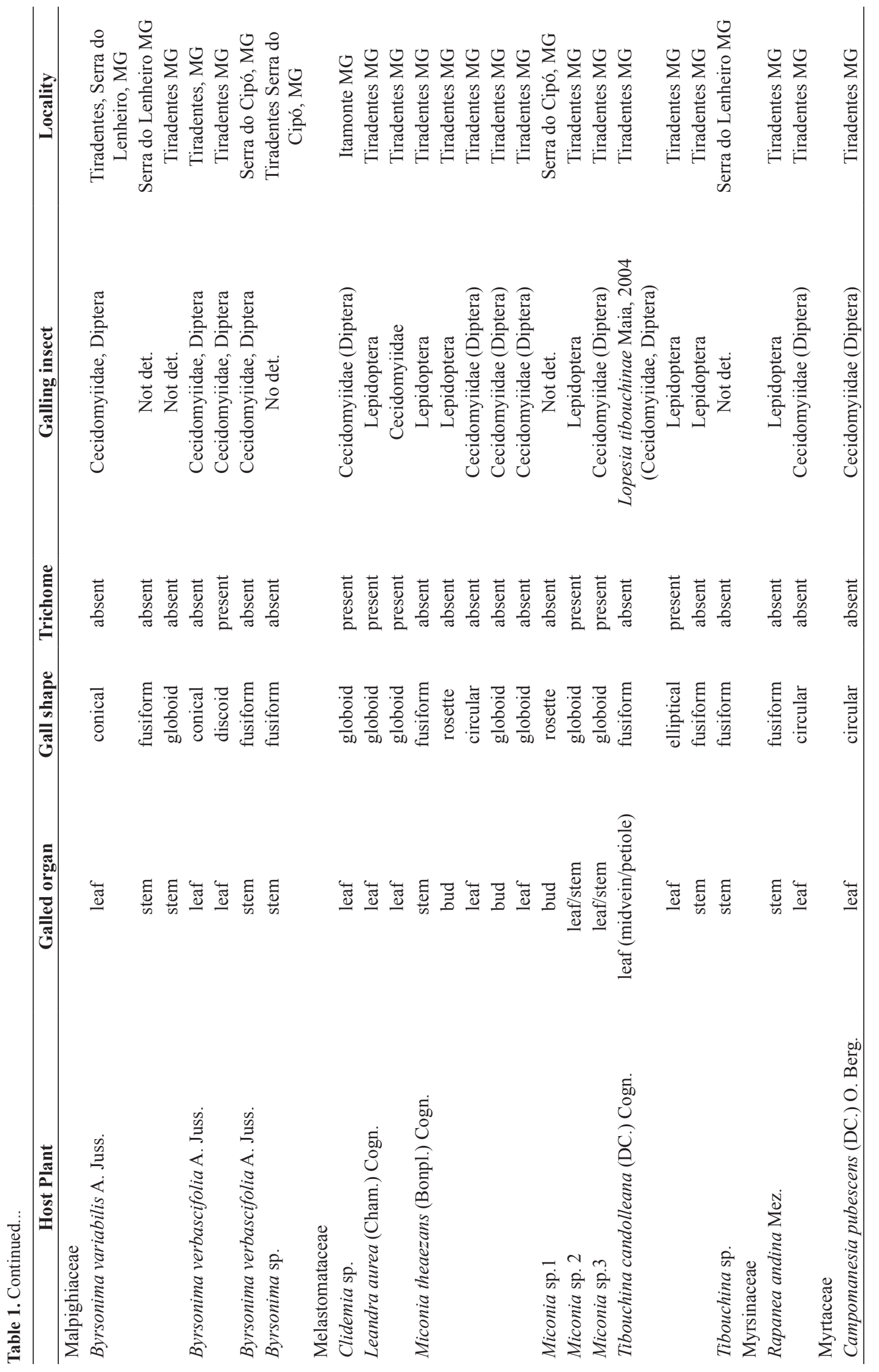




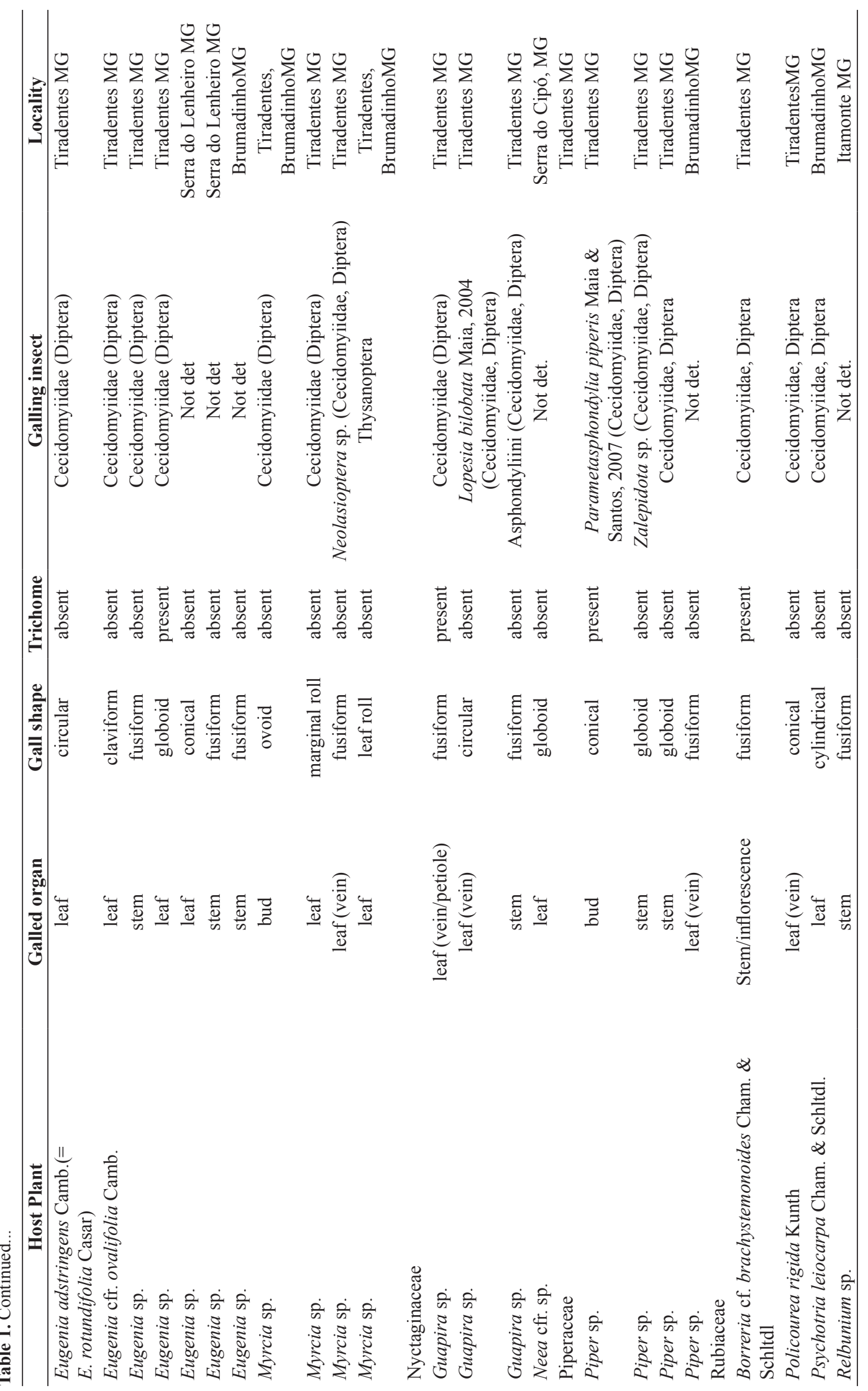




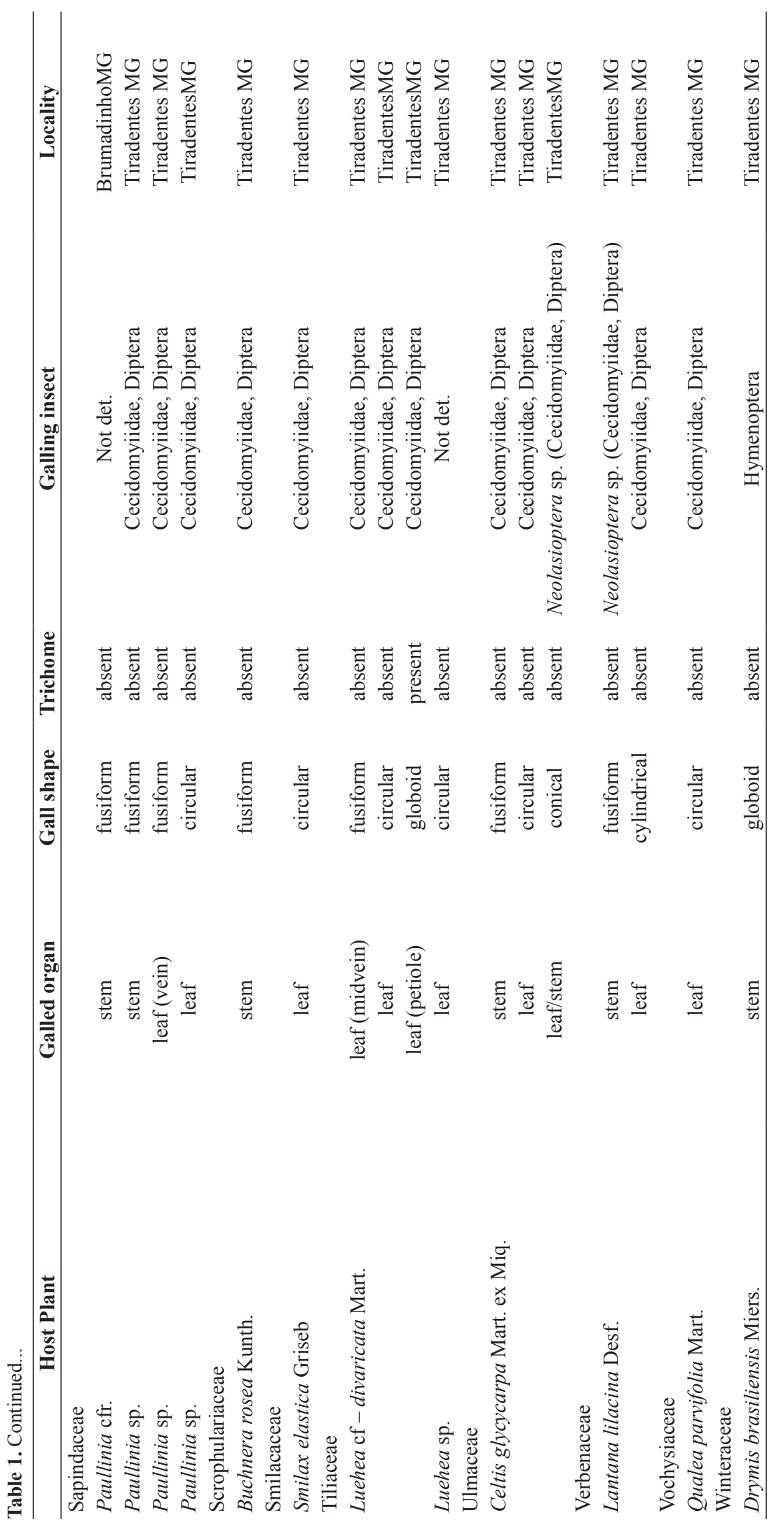


Table 2. Distribution of gall morphotypes in the most galled plant families.

\begin{tabular}{lc}
\hline \multicolumn{1}{c}{ Host plant family } & Number of gall morph types \\
\hline Melastomataceae & 15 \\
Asteraceae & 14 \\
Fabaceae & 13 \\
Myrtaceae & 12 \\
Euphorbiaceae & 11 \\
\hline
\end{tabular}

Table 3. Distribution of gall morphotypes in the most galled plant genera.

\begin{tabular}{lc}
\hline \multicolumn{1}{c}{ Host plant genus } & $\begin{array}{c}\text { Number of gall morph } \\
\text { types }\end{array}$ \\
\hline Croton (L.) Müll.Arg. & 10 \\
Miconia Ruiz \& Pav. & 07 \\
Eugenia L. & 07 \\
Baccharis L. & 06 \\
Byrsonima Rich. ex Kunth & 06 \\
\hline
\end{tabular}



$$
\square \text { Leaf } \square \text { Stem } \square \text { Bud } \quad \text { Flower }
$$

Figure 15. Distribution of gall morphotypes per plant organ. The total of the percentages is higher than $100 \%$ because some morphotypes were recorded on two plant organs.

Table 4. Distribution of gall morphotypes per shape.

\begin{tabular}{lc}
\hline \multicolumn{1}{c}{ Gall shape } & Number of morph types \\
\hline Fusiform & $41(31.3 \%)$ \\
Globoid & $39(27.5 \%)$ \\
Circular & $15(11.4 \%)$ \\
Ovoid & $09(6.9 \%)$ \\
Conical & $08(6.1 \%)$ \\
Marginal roll & $07(5.3 \%)$ \\
Rosette & $04(3.0 \%)$ \\
Cylindrical & $03(2.3 \%)$ \\
Vermiform & $01(0.76 \%)$ \\
Horn-shaped & $01(0.76 \%)$ \\
Claviform & $01(0.76 \%)$ \\
Leaf roll & $01(0.76 \%)$ \\
\hline
\end{tabular}

being Cecidomyiidae (Diptera) the most frequent galling insect (with 73\%) (Figure 16), as in all other zoogeographic areas (Felt, 1940). Most part of the gallers are identified at family level (52\%), 16\% are not determined, $6 \%$ are identified at genus and $13 \%$ at species. These data reveal how the taxonomy of the gallers is still little studied.

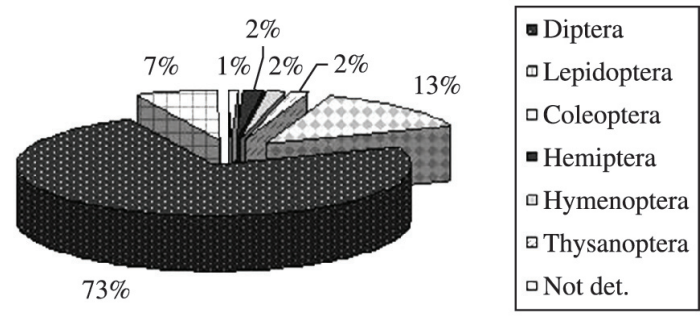

Figure 16. Distribution of gall morphotypes per order of galling insect.

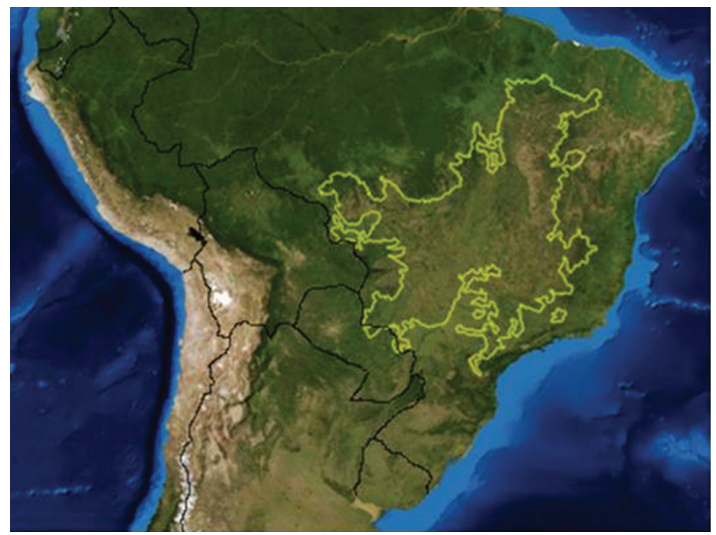

Figure 17. Map of the Cerrado ecoregion. Source: $<\mathrm{http}: / /$ pt.wikipedia.org/wiki/Cerrado>.

\section{Conclusion}

The Cerrado gall collection of the Museu Nacional comprises exclusively samples of rupestrian fields from Minas Gerais, totalling 131 morphotypes. It can be considered representative of this physiognomy in Minas Gerais. As the Cerrado spreads over other Brazilian states (Figure 17), efforts to obtain samples from these areas are necessary in order to increase the representativeness of the gall collection of the Museu Nacional.

\section{Acknowledgements}

We are grateful to CNPq for financial support (VCM Proc. 300237/2010-3, and SA Proc. 372165/2012-5).

\section{References}

BENITES, VM., SCHAEFER, CEGR., SIMAS, FNB. and SANTOS, HG., 2007. Soils associated with rock outcrops in the Brazilian mountain range Mantiqueira and Espinhaço. Revista Brasileira de Botânica, vol. 30, p. 569-577.

FLOATE, K., FERNANDES, GW. and NILSSON, J., 1996. On the use of galls as bioassays to identification of plant genotypes. Oecologia, vol. 105, p. 221-229.

FELT, EP., 1940. Plant galls and gall makers. Ithaca: Comstock . $364 \mathrm{p}$. 
GIULIETTI, AM., MENEZES, NL., PIRANI, JR., MEGURO, M. and WANDERLEY, MGL., 1987. Flora da Serra do Cipó, Minas Gerais: caracterização e lista das espécies. Boletim de Botânica da Universidade de São Paulo, vol. 9, p. 1-151.

GIULIETTI, AM., PIRANI, JR. and HARLEY, RM., 1997. Espinhaço range region, eastern Brazil. In DAVIS, SD., HEYWOOD, VH., HERRERAMACBRYDE, O., VILLA-LOBOS, J. and HAMILTON, AC. (Eds.). Centres of Plant Diversity: a Guide and Strategy for Their Conservation. Cambridge: WWF/IUCN. p. 397-404. vol. 3.

GIULIETTI, AM. and PIRANI, JR., 1988. Patterns of Geographic Distribution of some Plant Species from the Espinhaço Range, Minas Gerais, Brazil. In VANZOLINI, PE. and HEYER WR. (Eds.). Proceedings of a Workshop on Neotropical Biodiversity Distribution Patterns. Rio de Janeiro: Academia Brasileira de Ciências. p. 39-69.

HOUARD, C., 1933. Les Zoocecidies des Plantes de I'Amerique du Sud et de I'Amerique Central. Paris: Hermann \& Cie. 549 p.

ISAIAS, RM., CARNEIRO, RG., OLIVEIRA, DC. and SANTOS, JC., 2013. Illustrated and annotated checklist of Brazilian gall morphotypes. Neotropical Entomology, vol. 42, no. 3, p. 230-239. http://dx.doi.org/10.1007/s13744-013-0115-7. PMid:23949804

JACOBI, CM., CARMO, FF., VINCENT, RC. and STEHMANN, JR., 2007. Plant communities on ironstone outcrops: a diverse and endangered Brazilian ecosystem. Biodiversity and Conservation, vol. 16, no. 7, p. 2185-2200. http://dx.doi.org/10.1007/s10531007-9156-8.

JEPSON, W., 2005. A disappearing biome? Reconsidering land-cover change in the Brazilian savanna. The Geographical Journal, vol. 171, no. 2, p. 99-111. http://dx.doi.org/10.1111/j.14754959.2005.00153.x.

MARRIS, E., 2005. Conservation in Brazil: the forgotten ecosystem. Nature, vol. 437, no. 7061, p. 944-945. http://dx.doi. org/10.1038/437944a. PMid:16222267

MENEZES, NL. and GIULIETTI, AM., 2000. Campos rupestres. In MENDONÇA, MP. and LINS, LV. (Eds.). Lista vermelha das espécies ameaçadas de extinção da flora de Minas Gerais. Belo Horizonte: Fundação Biodiversitas, Fundação Zoobotânica de Belo Horizonte. p. 65-73.
MYERS, N., MITTERMEIER, RA., MITTERMEIER, CG., DA FONSECA, GA. and KENT, J., 2000. Biodiversity hotspots for conservation priorities. Nature, vol. 403, no. 6772, p. 853-858. http://dx.doi.org/10.1038/35002501. PMid:10706275

OLIVEIRA, PS. and MARQUIS, RJ., 2002. The Cerrados of Brazil: ecology and Natural history of a Neotropical savanna. New York: Columbia University Press. 398 p.

PRICE, PW., WARING, GL. and FERNANDES, GW., 1986. Hypotheses on the adaptive nature of galls. Proceedings of the Entomological Society of Washington, vol. 88, p. 361-363.

RAPINI, A., DE MELLO-SILVA, R. and KAWASAKI, ML., 2002. Richness and endemism in Asclepiadoideae (Apocynaceae) from the Espinhaço Range of Minas Gerais, Brazil - a conservationist view. Biodiversity and Conservation, vol. 11, no. 10, p. 1733-1746. http://dx.doi.org/10.1023/A:1020346616185.

RATTER, JA., RIBEIRO, JF. and BRIDGEWATER, S., 1997. The Brazilian Cerrado Vegetation and Threats to its Biodiversity. Annals of Botany, vol. 80, no. 3, p. 223-230. http://dx.doi. org/10.1006/anbo.1997.0469.

RIBEIRO, KT. and FERNANDES, GW., 2000. Patterns of abundance of a narrow endemic species in a tropical and infertile montane habitat. Plant Ecology, vol. 147, no. 2, p. 205-217. http:// dx.doi.org/10.1023/A:1009883300536.

RIBEIRO, JF. and WALTER, BMT., 1998. Fitofisionomias do bioma cerrado. In: SANO, SM. and ALMEIDA, SP. (Eds.). Cerrado: ambiente e flora. Planaltina: EMBRAPA-CPAC. p. 89-166.

SAFFORD, HD., 1999. Brazilian Páramos I. An introduction to the physical environment and vegetation of the campos de altitude. Journal of Biogeography, vol. 26, no. 4, p. 693-712. http://dx.doi.org/10.1046/j.1365-2699.1999.00313.x.

SHORTHOUSE, JD. and ROHFRITSCH, O. (Eds.), 1992. Biology of insect-induced galls. New York: Oxford University Press. 728 p.

WEIS, AE., WOLFE, CL. and GORMAN, WL., 1989. Genotypic variation and integration in histological features of the goldenrod ball gall. American Journal of Botany, vol. 76, no. 10, p. 15411550. http://dx.doi.org/10.2307/2444442. 